\title{
Temporal dynamics of organic matter, hyphomycetes and invertebrate communities in a Brazilian savanna stream
}

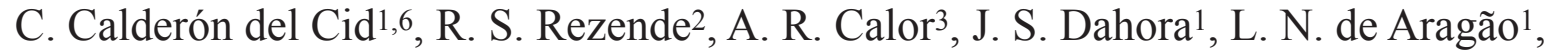
M. L. Guedes ${ }^{4}$, A. N. Caiafa ${ }^{5}$ and A. O. Medeiros ${ }^{1}$

${ }^{1}$ Laboratório de Microbiologia Ambiental, Instituto de Biologia, Universidade Federal da Bahia, CEP 40170-110, Salvador, Bahia, Brasil

2Programa de Pós graduação em Ciências Ambientais, Universidade Comunitária da Região de Chapecó Unochapecó, CEP: 89809-000, Santa Catarina, Brasil

${ }^{3}$ Laboratório de Entomologia Aquática, Instituto de Biologia, Universidade Federal da Bahia, CEP 40170-110, Salvador, Bahia, Brasil

${ }^{4}$ Herbário Alexandre Leal Costa, Instituto de Biologia, Universidade Federal da Bahia, CEP 40170-110, Salvador, Bahia, Brasil

${ }^{5}$ Laboratório de Ecologia Vegetal e Restauração Ecológica, Centro de Ciências Agrárias, Ambientais e Biológicas, Universidade Federal do Recôncavo da Bahia, CEP: 443800-000, Cruz das Almas, Bahia, Brasil

${ }^{6}$ Corresponding author.E-mail: caldecid@gmail.com

Keywords: Decomposer community; Ecosystem nutritional balance; Leaf litter breakdown; Physical fragmentation.

\begin{abstract}
Leaf litter breakdown is an important process in riparian ecosystems, regulated by the concomitant fluctuations of allochthonous organic matter input (quality and quantity), the environmental conditions, and the decomposer community. Our objective was to assess the effects of temporal variability of litter quantity and quality over the stream's decomposer community. We hypothesized that the litter effects over the decomposer community would be overruled by Cerrado's harsh environmental conditions. Precipitation fluctuations, especially during dry and rain seasons, did modify the litterfall periodicity, but not the average organic matter entering the system or the litterfall triggers. Fifteen riparian species were identified contributing with organic matter into the stream, however, Richeria grandis contributed with $48 \%$ of litter biomass, helping explain the nutritional intra-annual balance given by the litter chemistry, that would be determinant for ecosystem stability. Higher aquatic hyphomycetes sporulation rates and invertebrate density during the dry season suggest that the decomposer community required a more stable environment (consistent low current) in order to colonize and exploit leaf litter. Our results point out that physical fragmentation was the predominant driver of litter breakdown for our system, due to high decomposition rates, litter remaining mass correlated negatively with precipitation, and low decomposer abundance and activity. Invertebrate collectors' abundance was negatively correlated with litter remaining mass and showed no temporal variation, suggesting that this functional group may have benefited from the particulate organic matter produced by physical fragmentation. Therefore, annual temporal variations on Brazilian savanna stream systems may drive the functioning of the ecosystem.
\end{abstract}

Abbreviations: AFDM-Ash-free dry mass; AOM-Allochthonous Organic Matter; BS-Benthic Stock; C/N-carbon-to-nitrogen ratio; $\chi 2$-Chi-square distribution; $k$-litter breakdown rates; ind-individual; LI-Lateral Input; PerMANOVA-Permutational Multivariate Analysis of Variance; TI-Terrestrial Input; VI-Vertical Input.

\section{Introduction}

Litter breakdown in streams may be driven mainly by water and litter chemical characteristics and the trophic interaction of the microbial and invertebrate decomposer community (Abelho 2001, Boyero et al. 2016, García-Palacios et al. 2016). The identification of effect size between abiotic and biotic factors that drive the litter decomposer process is essential to develop models that may predict organic matter dynamics, nutrient cycling and carbon sequestration on riparian zones (Abelho 2016). The high complexity of riparian zones, due to transitional characteristics between aquatic and terrestrial systems, increases spatial and temporal variation in litter breakdown process (Boyero et al. 2015). At larger scales, the major factors driving, spatially and temporally, the decomposition process are the geology and climate (Graça et al. 2015), while at a smaller scale the decomposer community stands out, especially the hyphomycetes and shredders seasonal variability (Graça et al. 2016, Wootton et al. 2018). However, effects on different scales (large to small) influence each other in a complex hierarchical system (Peters et al. 2007).

Geology defines soil composition, which drives litter breakdown through two mechanisms: i) soil chemical content determines nutrient concentration in plants, and consequently, in leaf litter; ii) soil nutrient composition, alongside the hydrological regime, controls the dissolved nutrients in water stream (Boulton et al. 1998, Graça et al. 2015, Ordoñez et al. 2009). First, if plants grow in a poor nutrient soil, low quality 
litter, characterized by low content of nitrogen and high content of structural compounds (Leite-Rossi et al. 2016, Li et al. 2009), would enter into the stream, discouraging microbial colonization (Ferreira et al. 2012, Graça et al. 2016) and, consequently, reducing palatability for shredders (Ligeiro et al. 2010, Wantzen and Wagner 2006), hindering the biological mediated decomposition. Secondly, aquatic hyphomycetes, the protagonist fungi in the leaf litter-breakdown (Butler and Suberkropp 1986, Suberkropp and Klug 1976), absorb nutrients from stream water and if these are scarce, then the fungal growth and activity would be limited (Gulis and Suberkropp 2003). Therefore, poor soils may diminish the decomposer community predominance over the detrital breakdown process (Graça et al. 2015).

Such poor soil scenario, associated to low litter quality and few dissolved nutrients, with its consequences for litter breakdown process in streams, can be found in the Brazilian savanna, also called Cerrado (Marques et al. 2004, Parron et al. 2011). A poor soil scenario in Cerrado has been described as the main responsible for low litter decomposition rates, as well as the low density and activity of the decomposer community (aquatic hyphomycetes fungi and aquatic invertebrates) on streams systems (Alvim et al. 2015, Gonçalves et al. 2007, Sales et al. 2015). The principal promotor of litter breakdown, when the environmental and resource conditions affect adversely the decomposer community of a given system, is the physical fragmentation caused by the stream current (Graça et al. 2015). Physical fragmentation come by three ways: i) sediment transported by streamflow may impact and erode the litter (Ferreira et al. 2006); ii) irregular hydrological pulses (water erosion, Rueda-Delgado et al. 2006), and iii) eventual spates that may score and drag downstream the litter benthic stock (Jones 1997, Tank et al. 2010).

Riparian vegetation, by leaching its litter chemical content, may compensate the effects of poor soil over water nutrients (Dosskey et al. 2010, Shaftel et al. 2012). Also, higher nutrient leaching on leaf litter may stimulate aquatic hyphomycetes community decomposing activity and grow (Graça et al. 2016). This effect would be inflicted by temporal variability of litter biomass (Bambi et al. 2017, Tonin et al. 2017, Webster and Meyer 1997), and riparian litter diversity (Rezende et al. 2017b), which would provide a variable nutrient input over the system. Nevertheless, it may exist, in some streams, an absence of riparian effect over water chemistry, due to dominant AOM contribution of few riparian species (Gonçalves et al. 2014) and AOM constant quality over seasons (Sales et al. 2015).

We present a patch scale study of organic matter dynamics in a Brazilian savanna low order stream to assess the effects of temporal variability of litter quantity and diversity over the decomposer community, and consequently, over the litter breakdown process. The experiment was designed to measure the intra-annual patterns of leaf litter breakdown and the associated biological communities (aquatic hyphomycetes fungi and aquatic invertebrates), simultaneously with the allochthonous organic matter variation input (by litter biomass and riparian species chemistry). We expected that the general effects of litter seasonal variability (in diversity and abundance terms) over the system would be overruled by the environmental conditions of Brazilian savanna, based on the existing evidence (Gonçalves et al. 2007, Sales et al. 2015, Wantzen 2003). We hypothesized that the decomposer community activity would not respond to the litter temporal variability (due to constancy on the stream litter bed and poor scenario of the riparian zone over a year), and consequently, litter breakdown would be promoted by other factors (such as physical fragmentation).

\section{Methods}

\section{Study area}

The experiment was conducted in the Boiadeiro stream

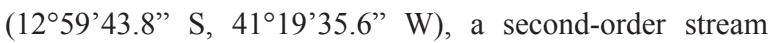
located in the Parque Municipal de Mucugê in Chapada Diamantina (Bahia, Brazil). It was carried on from January 2015 to January 2016. This park presents a high phytophysiognomy complexity; its vegetation is composed of mosaics of Brazilian savanna, ombrophilous and seasonal forest and Caatinga (Juncá et al. 2005). The riparian zone of Boiadeiro stream is a stratified riparian forest, with a minimum width of 10 meters; its physiognomy and structure are quite contrasting with respect to the predominant countryside formation of the surrounding. The climate is mesothermal, with seasonal variation of 15 to $30^{\circ} \mathrm{C}$. According to Santos et al. (2017), the site presents two well defined seasons: i) winter/dry (MayJuly), ii) summer/rain (November-January); and also shows two transitional seasons, according to the historical precipitation graphic (Fig. 1): i) rain-dry (February-April), ii) dryrain (August-October). The seasons defined above were used to assess the decomposer community temporal variation. Because the study was conducted in a single stream, the results should be interpreted with caution.

\section{Water and climatic parameters}

During the experiment the following water parameters were measured: temperature (Hach), $\mathrm{pH}$ (Hach), dissolved oxygen (Oximeter, Hach), light (MLM-1011, Minipa), chanel deepness (FP111, Global Water), water velocity (FP111, Global Water). Water samples were collected monthly to determine chemical concentrations by means of ion chromatography according to the methods described in APHA (1999). The monthly precipitation and temperature information was obtained through the Water National Agency (ANA, by its Portuguese acronym) website (http://hidroweb.ana.gov.br/), utilizing the Mucugê city meteorological station (number 1241033; located at $13^{\circ} 1^{\prime} 37.1994 " \mathrm{~S}, 41^{\circ} 13^{\prime} 16.32^{\prime \prime} \mathrm{W}$ ) (Supplement: Table SM1).

\section{Allochthonous organic matter (AOM) dynamics}

The AOM was measured at the beginning of each season (January, April, July, and October). Measurements were taken 
from three points along the stream, distanced from each other by 40 meters. Terrestrial Input (TI), the AOM falling directly to the ground, was measured employing 6 nets $\left(1 \mathrm{~m}^{2}\right.$ with $1-\mathrm{mm}$ mesh size, suspended to the ground at a height of $1 \mathrm{me}-$ ter), distributed one at each point margin. Lateral Input (LI), the AOM accumulated in the margin, was measured by 6 nets $(0.2 \mathrm{~m}$ height $\times 0.5 \mathrm{~m}$ width, $1 \mathrm{~mm}$ mesh size; distributed one at each point margin) with the opening towards the terrestrial system. Benthic stock (BS) was collected at each point employing a Surber sampler $\left(0.45 \mathrm{~m}^{2}, 250 \mu \mathrm{m}\right.$ mesh size $)$. Each point, for Vertical Input (VI), was arranged perpendicularly to the riverbed at a height of 2 meters and it was constituted by 18 buckets $(25 \mathrm{~cm}$ diameter and pierced to avoid water retention), distributed equally along 3 rows. The two baskets of each row which contained the highest leaf material weight were selected for the litter breakdown experiment (forming 6 samples per point; explained in the next section). The rest of the material (including TI, LI, and BS) was taken to laboratory and oven-dried at $60^{\circ} \mathrm{C}$ for $72 \mathrm{~h}$, weighted in a scale (BEL engineering, precision: $\pm 0.001 \mathrm{~g}$ ), and identified to species level (Angiosperm Phylogeny Group system classification (Chase et al. 2016).

\section{Leaf-litter breakdown, chemical analyses, and decomposer community}

The leaf samples selected from the buckets were weighed to establish the initial wet mass and then placed into litter bags $(30 \mathrm{~cm} \times 30 \mathrm{~cm}$; with a $10 \mathrm{~mm}$ mesh size), constituting 18 litterbags that were incubated simultaneously in the stream water (distributing 6 in the 3 referred points). In order to determine the initial dry mass of the incubated samples, the leaves that were not used for the litter-breakdown

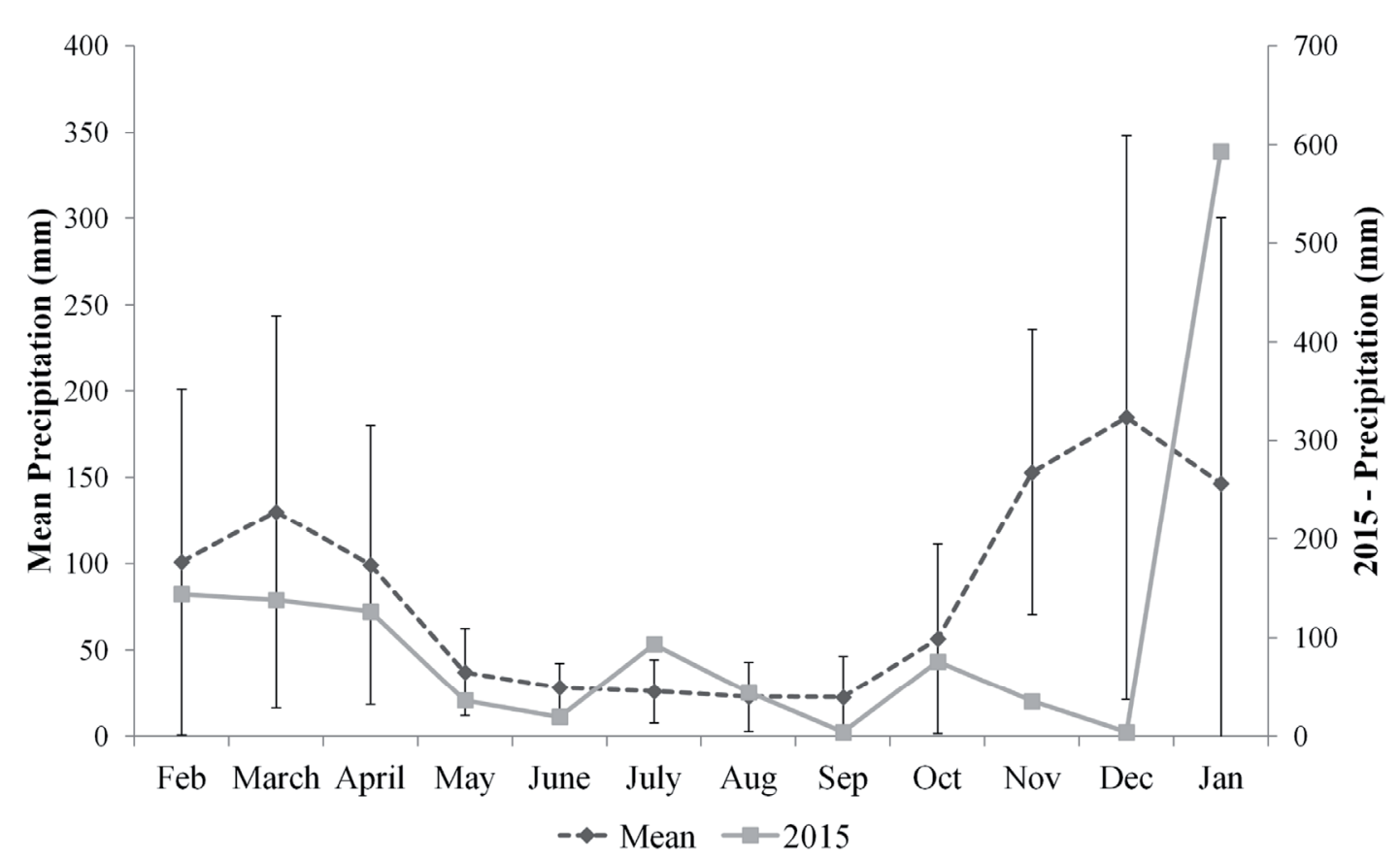

Figure 1. Monthly mean values ( \pm SE) for historical precipitation from 1985 to 2016 (dashed line), and from Feb-Dec of 2015 and Jan 2016 (solid line). experiment were weighed and then dried $\left(60^{\circ} \mathrm{C}\right.$ for $\left.72 \mathrm{~h}\right)$ to be weighed again to establish a conversion factor (initial dry mass / initial wet mass) which was multiplied by the initial wet mass of the samples. Afterwards, 2 litterbags per point were removed (6 in total) at 30, 60 and 90 days. This procedure was repeated 4 times, one for each season, in order to assess temporal changes in litter breakdown and associated decomposer community. The litterbags removed were folded in plastic bags, introduced into an ice cooler and transported to the laboratory. Over a $180-\mu \mathrm{m}$ sieve, leaf litter was washed with distilled water, pressing carefully litter's surface in order to remove the associated invertebrates. The material captured by the sieve was placed into a plastic flacon, fixing it $(80 \%$ ethanol) for posterior invertebrate count and identification to family level and trophic functional group, according to Mugnai et al. (2009) and Hamada et al. (2014). Then, 3 sets of 5 discs each (12 mm diameter) were removed randomly from each leaf sample to analyze the next parameters: i) Ash-free dry mass (AFDM; $550^{\circ} \mathrm{C}$ for 4 hours), ii) sporulation and fungal community, iii) ergosterol concentration. Final dry mass adding the dry mass of the discs removed.

The remaining leaf mass was determined using the next operation: (initial dry mass - final dry mass) $\times$ AFDM factor. The leaf samples, after the disc-removal, were powder ground and passed through a $0.1 \mathrm{~mm}$ sieve, and enveloped in tin sheets. Carbon and nitrogen percentages over total leaf mass were quantified through the biomass combustion process in CNS auto-analyzer (CNS 628, Leco, St. Joseph - Mi, EUA). The combustion was made in oxygen excess $\left(\mathrm{H}_{2} \mathrm{O}<3\right.$ ppm, $\mathrm{CnHm}<5$ ppm; White Martins) to $950{ }^{\circ} \mathrm{C}$. Helium gas (He) $\left(\mathrm{H}_{2} \mathrm{O}<3\right.$ ppm, $\left.\mathrm{O}_{2}<2 \mathrm{ppm}\right)$ was used as chromatograph gas carrier at a $669 \mathrm{mmHg}$ pressure. Phenolic concentration was determined by drying the leaf sample $\left(60^{\circ} \mathrm{C}\right.$ for $\left.72 \mathrm{~h}\right)$ and 
was measured through the compound extraction in $5 \mathrm{~mL}$ of $70 \%$ acetone, according to Bärlocher and Graça (2005). The same methodology was applied over the riparian species leaves that contributed to the AOM input (VI, LI, TI) over the 4 months described above.

The sporulation and aquatic hyphomycetes community in the leaves discs were obtained according to the methodology established by Bärlocher (2005). The discs were introduced in Erlenmeyer flasks containing $30 \mathrm{~mL}$ of distilled water. The flasks were installed over an orbital shaker $(90 \mathrm{rpm})$ for 48 hours at $18{ }^{\circ} \mathrm{C}$. Afterwards, the distilled water containing the liberated spores was filtered through a Millipore membrane filter ( $25 \mu \mathrm{m}$ diameter, Millipore Corporation, Bedford, MA, USA). The reminiscent material was stained by means of cotton blue in lactophenol. Finally, the spores were examined through an optical microscope $(\times 400$, Olympus BX 43$)$, for conidial counting (spores/mg of AFDM/day) and to identify the aquatic hyphomycetes community by utilizing taxonomic keys developed for tropical biomes (Fiuza et al. 2017, Gulis et al. 2005).

The ergosterol concentration in the leaf discs was obtained according to the methodology established by Gessner, (2005). The ergosterol is a major membrane component and a target substance of the fungal community. The leaf discs were introduced in alkaline methanol for lipid extraction, and purified through solid-phase extraction. Then, ergosterol concentration was determined by means of high-performance liquid chromatography. The concentration values were expressed as $\mu \mathrm{g}$ ergosterol.g-1 AFDM.

\section{Statistical analysis}

We employed the negative exponential model for obtaining the litter breakdown rates $(k)$ throughout the seasonal $\left(30,60,90\right.$ days) incubation $\left(\mathrm{W}_{\mathrm{t}}=\mathrm{W}_{\mathrm{o}} \mathrm{e}^{-\mathrm{kt}}, \mathrm{W}_{\mathrm{t}}=\right.$ remaining mass, $\mathrm{W}_{\mathrm{o}}=$ initial mass, $-k=$ litter breakdown rate, $\mathrm{t}=$ time). Multiple linear regression was performed for assessing relationships between remaining mass and climatic variables (air temperature, light, precipitation), physical and chemical water characteristics (water flow, $\mathrm{pH}$, dissolved oxygen, ammonium, potassium, nitrite, nitrate, sulfate). The linear mixed-effects analysis (lme4; (Bates et al. 2015) was performed for testing temporal variations (explanatory variable) of remaining mass, litter carbon-to-nitrogen ratio $(\mathrm{C} / \mathrm{N})$ and Phenols, BS abundance, ergosterol content, abundance and richness of AOM inputs (VI, LI, TI), aquatic hyphomycetes, invertebrates, shredders, scrapers and collectors (response variables). Season was considered as a fixed effect. We considered, for AOM inputs and BS, one random effect: Sampling points, for removing spatial pseudoreplication. We considered, for the other variables, two random independent effects: (1) Months, for removing temporal pseudoreplication; (2) Sampling points, for removing spatial pseudoreplication. The p-values were obtained by likelihood ratio tests (Chi-square distribution) of the full model against a partial model without the explanatory variable. Contrast analyses among seasons and months were performed using the multcomp package (Hothorn et al. 2009). General linear hypoth- eses, employing multiple comparisons of means as Tukey contrasts, were performed to test specific differences among seasons and months.

The correlation between the decomposer community attributes (ergosterol content, sporulation rates, shredders, scrapers, and collectors' abundance) and litter remaining mass was assessed by nonparametric Spearman rank correlation. PerMANOVA analysis was performed for testing temporal variations (seasons or months; explanatory variable) of the decomposer and riparian leaf community composition (response variable). A pairwise contrast matrix was employed to test differences among specific seasons or months. The aquatic invertebrate community was assigned to trophic functional groups and arranged in terms of occurrence and frequency. The aquatic hyphomycetes and riparian leaf communities also were arranged in terms of occurrence and frequency of species. PerMANOVA analysis was also used to determine leaf chemical composition (Carbon, Nitrogen, and Phenols) percentage (\%) and total (g. $\left.\mathrm{m}^{-2}\right)$ differences among months (explanatory variable). Carbon, Nitrogen, and Phenols were not evaluated separately because they are highly correlated due to being measured from the same leaf samples.

An analysis of the indicator species, as proposed by Dufrêne and Legendre (1997), was used to determine which organisms (aquatic hyphomycetes, invertebrate functional group, and riparian leaf species) were characteristic of the season. This analysis uses the frequency and density of the organisms in the previously defined groups and produces an indicator value ranging from 0 (non-indicator) to 1 (perfect indicator). Significance was tested using Monte Carlo tests with 1000 permutations and set to $\mathrm{p}<0.05$.

\section{Results}

\section{Precipitation for the 2015 year}

Transitional rain-dry season (February-April) presented a precipitation pattern similar to the historical precipitation mean (inside the standard deviation). Dry season (May-July) presented a regular pattern in the first two months; however, July showed a precipitation level outside of the standard deviation. Transitional dry-rain season (Augustus-October) showed a pattern similar to the historical precipitation mean. Rain season (November-January) presented a pattern completely outside the standard deviation, with a severe drought in the first two months and a heavy rain in the last one (Fig. 1).

\section{AOM dynamics}

The mean AOM Vertical (VI), Lateral (LI), and Terrestrial (TI) input was 24,49 , and $45 \mathrm{~g} . \mathrm{m}^{-2} \mathrm{month}^{-1}$, respectively. The VI was significantly different among months $(\chi 2(3)=17.08$, $\mathrm{p}<0.001$ ), with the lowest mean value (general linear hypotheses, $\mathrm{p}<0.05)$ occurring in April $\left(16.74 \pm 12.42\right.$ g.m-2 ${ }^{-2}$. The LI was significantly different among months $(\chi 2(2)=$ 15.23, $\mathrm{p}<0.001)$, with October $\left(76.75 \pm 44.62\right.$ g.m $\left.\mathrm{m}^{-2}\right)$ being the highest value (general linear hypotheses, $\mathrm{p}<0.001$ ). The 
Table 1. Percentage carbon $(\% \mathrm{C})$, percentange nitrogen $(\% \mathrm{~N})$, percentage phenols (\%Phe), vertical (VI), horizontal (HI), and terrestrial (TI) organic input and benthic standing stock (BS) estimated monthly (mean $\pm \mathrm{SE}$ ) for each riparian species $\left(\mathrm{g} / \mathrm{m}^{2}\right)$ over the beginning of each season (January, April, July and October/2015).

\begin{tabular}{|c|c|c|c|c|c|c|c|}
\hline Species & $\% \mathrm{C}$ & $\% \mathrm{~N}$ & $\%$ Phe & VI & LI & $\mathrm{TI}$ & BS \\
\hline $\begin{array}{l}\text { Agarista oleifolia (Cham.) G. } \\
\text { Don var. }\end{array}$ & 55.97 & 0.72 & 20.53 & $4.74 \pm 9.92$ & - & - & - \\
\hline $\begin{array}{l}\text { Alchornea triplinervia (Spreng.) } \\
\text { Müll. Arg. }\end{array}$ & 51.13 & 0.85 & 26.95 & $2.36 \pm 3.95$ & $5.85 \pm 11.49$ & $37.22 \pm 128.67$ & - \\
\hline $\begin{array}{l}\text { Bonnetia stricta (Nees) Nees \& } \\
\text { Mart. }\end{array}$ & 53.90 & 0.61 & 32.17 & $18.99 \pm 31.54$ & $8.38 \pm 21.29$ & $2.91 \pm 5.70$ & $0.97 \pm 3.08$ \\
\hline Clusia nemorosa G. Mey. & 55.50 & 0.41 & 32.64 & - & - & $130.68 \pm 422.69$ & $4.96 \pm 15.67$ \\
\hline Doliocarpus elegans Eichler & 55.88 & 0.66 & 39.03 & $6.20 \pm 21.46$ & - & - & - \\
\hline Eugenia angustissima $\mathrm{O}$. Berg. & 52.13 & 0.80 & 18.27 & $0.20 \pm 0.48$ & - & $1.05 \pm 3.64$ & - \\
\hline Geonoma brevispatha Barb. Rodr. & 8.58 & 0.10 & 6.95 & - & - & $5.24 \pm 18.14$ & - \\
\hline $\begin{array}{l}\text { Laplacea fruticosa (Schrad.) } \\
\text { Kobuski }\end{array}$ & 53.52 & 0.58 & 48.33 & $7.34 \pm 11.33$ & $105.82 \pm 133.03$ & $26.99 \pm 43.36$ & $3.96 \pm 11.91$ \\
\hline $\begin{array}{l}\text { Myrsine guianensis (Aubl.) } \\
\text { Kuntze }\end{array}$ & 42.15 & 0.90 & 20.53 & $17.37 \pm 25.11$ & $0.73 \pm 1.92$ & - & - \\
\hline Persea aurata Miq. & 53.33 & 0.64 & 15.51 & - & - & $0.98 \pm 3.38$ & - \\
\hline Richeria grandis Vahl & 51.34 & 0.91 & 18.89 & $4.19 \pm 7.35$ & $245.99 \pm 496.83$ & $369.04 \pm 713.10$ & $77.94 \pm 225.62$ \\
\hline Roucheria columbiana Hallier & 53.04 & 0.91 & 24.55 & - & $2.18 \pm 5.77$ & $69.25 \pm 231.17$ & $21.22 \pm 67.09$ \\
\hline Tibouchina barnebyana Wurdack & 56.46 & 0.70 & 21.28 & $86.71 \pm 59.07$ & $26.26 \pm 45.08$ & $0.77 \pm 2.68$ & $1.22 \pm 3.34$ \\
\hline Unidentified species & - & - & - & $0.81 \pm 2.26$ & - & - & - \\
\hline Vochysia acuminata Bong. & 52.98 & 1.15 & 36.23 & $28.74 \pm 55.87$ & $59.89 \pm 151.36$ & $0.33 \pm 0.80$ & $33.56 \pm 67.55$ \\
\hline
\end{tabular}

TI was significantly different among months $(\chi 2(3)=17.08$, $\mathrm{p}<0.05)$, with October $\left(70.94 \pm 58.16 \mathrm{~g} \cdot \mathrm{m}^{-2}\right)$ being the highest value (general linear hypotheses, $\mathrm{p}<0.05$ ) (Figure 2). The mean Benthic standing stock (BS) was 43.7 g. $\mathrm{m}^{-2}$ month $^{-1}$. Despite having its higher value in October $\left(64.6 \mathrm{~g} \cdot \mathrm{m}^{-2}\right)$, its variance was not temporally explained $\left(\chi^{2}(3)=6.61, \mathrm{p}=\right.$ $0.085)$.

Fifteen species of riparian leaves contributed to the organic matter input over the one-year study period (Table 1), however only 6 species contributed with more than $5 \%$ in AOM input: Richeria grandis Vahl (48\%); Clusia nemorosa G. Mey. (12\%); Tibouchina barnebyana Wurdack (9\%); Laplacea fruticosa (Scharad.) Kobuski (9\%); Roucheria columbiana Hallier (6\%); Vochysia acuminata Bong. (6\%). Riparian leaf richness for VI was significantly different among months $\left(\chi^{2}(3)=12.88, \mathrm{p}<0.01\right)$, with April, the lowest value $(2.26 \pm 1.15$ species $)$, being different (general linear hypotheses, $\mathrm{p}<0.05$ ). Riparian leaf richness LI and TI did not vary temporally. Riparian community (occurrence and frequency of species) differed among months for the whole input (PerMANOVA, F $(3,29)=1.847 ; \mathrm{p}<0.01)$, with October being significantly different from the other months (pairwise contrast, Bonferroni, $\mathrm{p}<0.05$ ). January and July did not show an indicator species. Geonoma brevispatha Barb. Rodr (IV = $0.5, \mathrm{p}<0.01$ ) was indicator for April; Richeria grandis (IV = $0.71, \mathrm{p}<0.001)$ and Laplacea fruticosa $(\mathrm{IV}=0.49, \mathrm{p}<0.05)$ were indicators for October. The \%Carbon, \%Nitrogen, and $\%$ Phenols of the AOM input (riparian species terms; Table 1) did not vary among months (PerMANOVA, F $(3,27)=0.85 ; \mathrm{p}$ $=0.49$ ). The total carbon, nitrogen, and phenols of the AOM input varied among months (PerMANOVA, $\mathrm{F}(3,27)=2.76$; $\mathrm{p}<0.05$ ), with October being significantly higher from July (pairwise contrast, Bonferroni, $\mathrm{p}<0.05$ ).

\section{Leaf litter breakdown}

The litter breakdown coefficients (k) were: $-0.035,-0.017$, -0.025 , and -0.011 day $^{-1}$ for transition rain-dry, dry, transition dry-rain, and rainy seasons, respectively. Remaining mass (Fig. 3) varied seasonally $(\chi 2(3)=53.532, \mathrm{p}<0.001)$; it was significantly higher during the rainy season (general linear hypotheses, $\mathrm{p}<0.001$, ) and lower during the transition rain-dry season. For climatic variables (adjusted $\mathrm{R}^{2}=0.4313$, $\left.\mathrm{F}_{(2,61)}=24.89 ; \mathrm{p}<0.001\right)$, the remaining mass just presented a negative relationship with precipitation (Beta $=-2.87$ ). For water physical and chemical properties (adjusted $\mathrm{R}^{2}=$ 


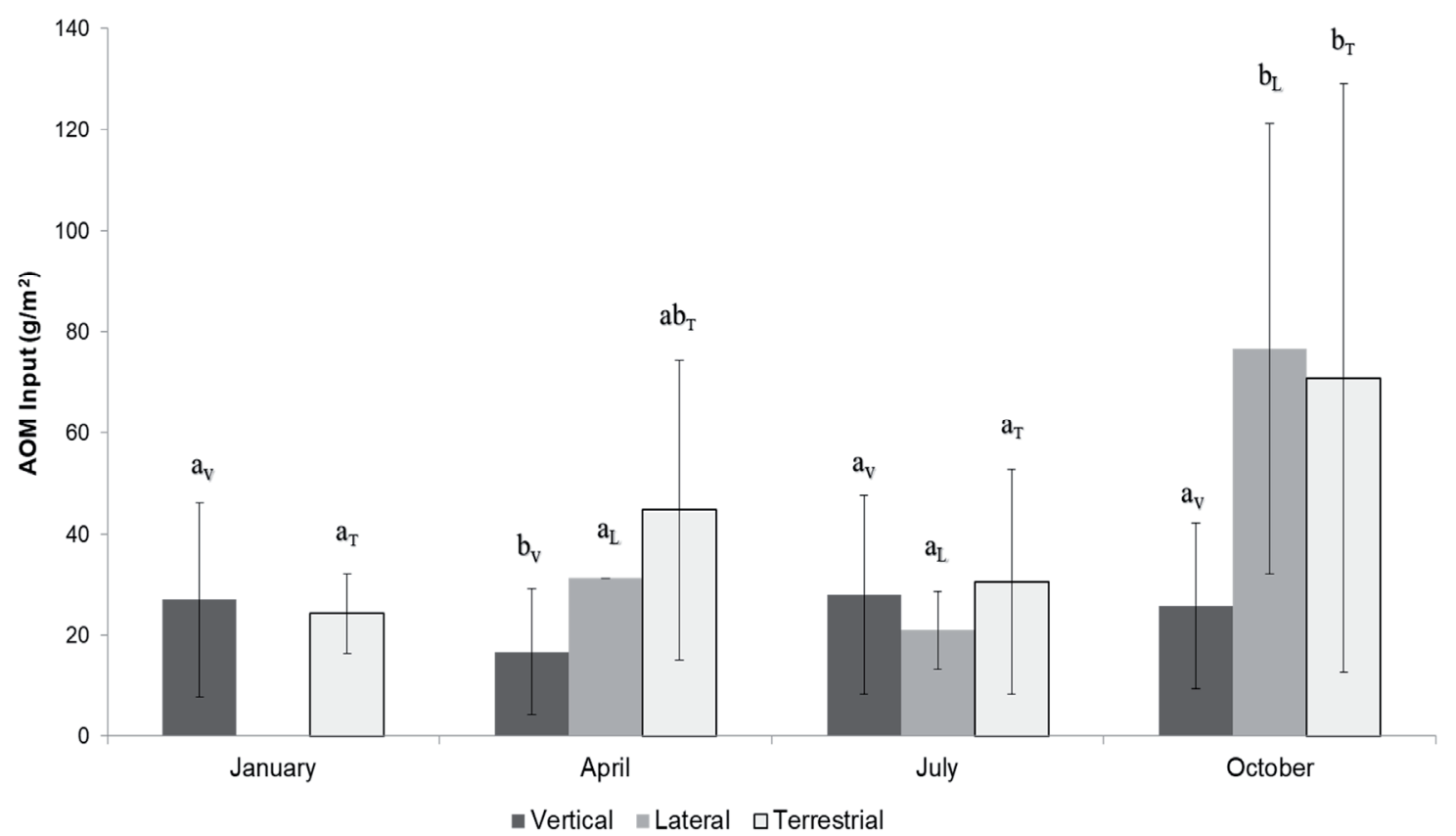

Figure 2. AOM input (vertical, lateral, and terrestrial; mean and standard error; principal axis) over the 4 months evaluated (January, April, July, October). Different letters ("a", "b") indicate significant differences for each input ("V","L","T" as subscripts).

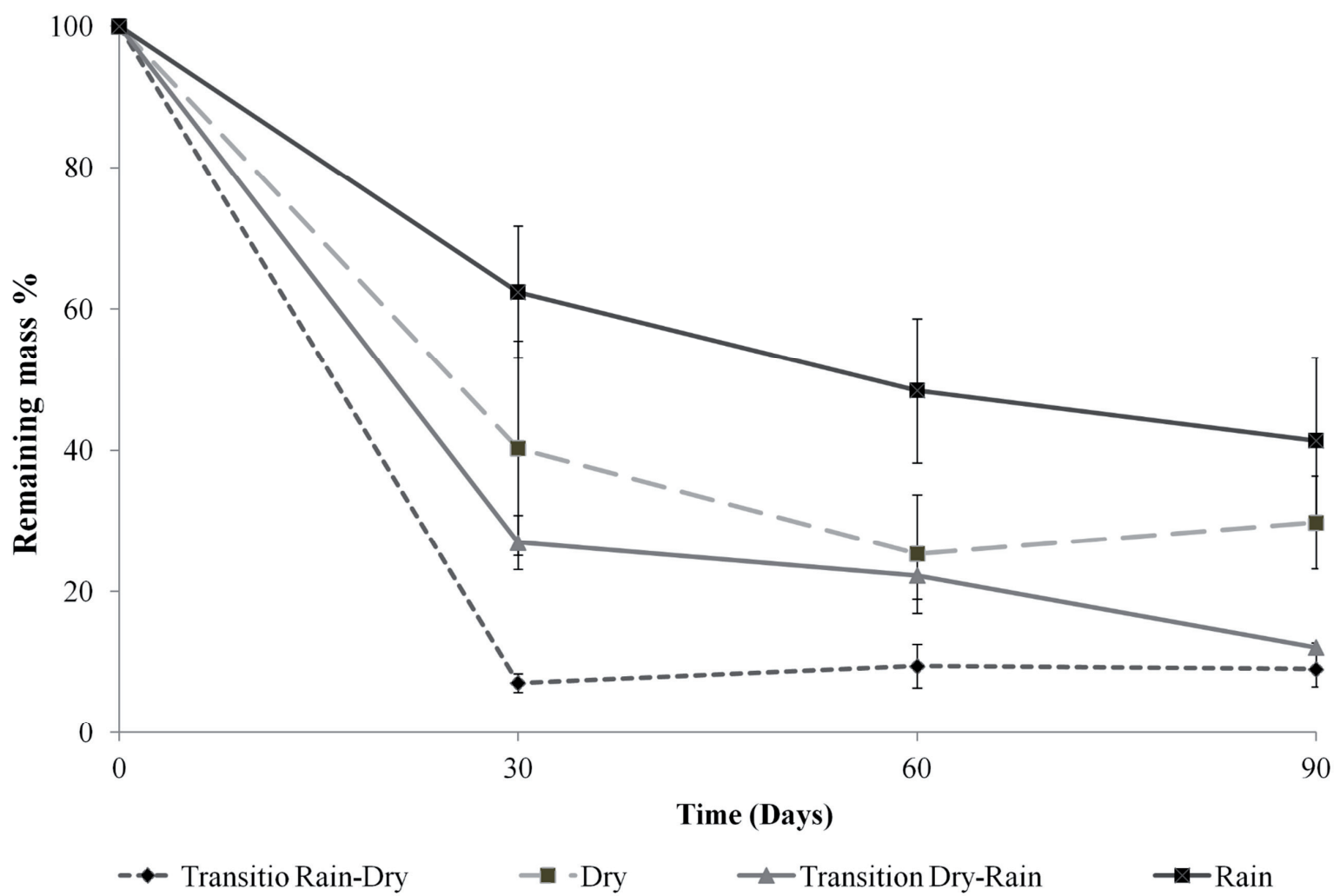

Figure 3. Remaining mass (mean \% and standard error) in seasonally basis terms (transition rain-dry (Feb-April); dry (May-July); transition dry-rain (August-October); rain (November-January). 
0.6037, $\left.\mathrm{F}_{(8,17)}=5.761 ; \mathrm{p}<0.01\right)$, the remaining mass showed a positive relationship with ammonium $($ beta $=0.784)$ and $\mathrm{pH}$ (beta $=16.251)$, but a negative relationship with nitrite (beta $=-0.558)$.

\section{Litter chemistry}

The $\mathrm{C} / \mathrm{N}$ of the incubated litter were $53,55,60$, and 58 for transition rain-dry, dry, transition dry-rain, and rain seasons, respectively. It did not vary among seasons $\left(\chi^{2}(3)=2.18\right.$, p $=0.54)$. The phenolic concentrations (Phenols $\%$ ) of the incubated litter were $4.58,5.29,6.64$, and $6.58 \%$ for transition rain-dry, dry, transition dry-rain, and rain seasons, respectively. It did not vary among seasons $\left(\chi^{2}(3)=4.78, p=0.19\right)$

\section{Decomposer community}

The ergosterol content varied seasonally $\left(\chi^{2}(3)=\right.$ $11.168, \mathrm{p}<0.05)$, with highest values $(292.55 \pm 147.82$
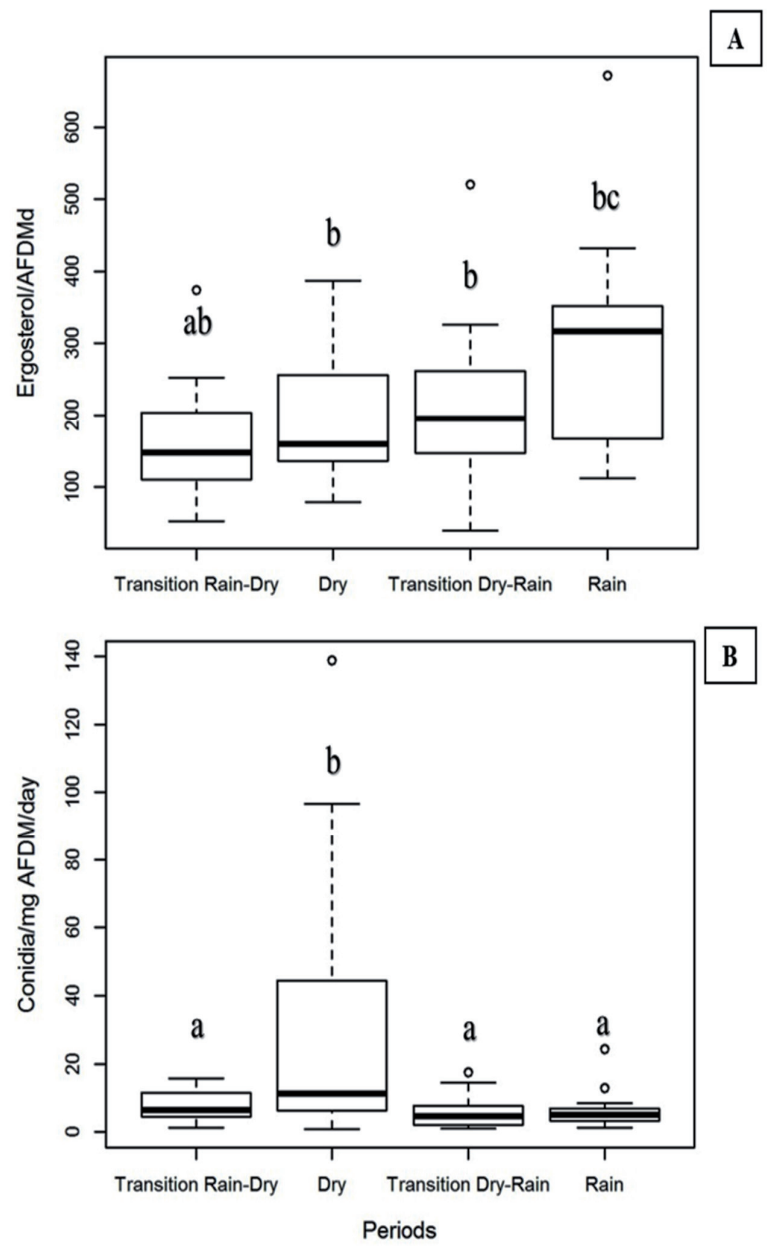

Figure 4. Ergosterol concentration in decomposing leaves (mean and standard error) among seasons (A) Conidial spores of aquatic hyphomycetes (mean and standard error) among seasons (B): the first (lower line) and third (higher line) quartile, the median (bold line), upper and lower limits (dashed line) and outliers (circles). Different letters ("a", "b", "c") indicate significant differences. $\mu \mathrm{g}$ ergosterol.g-1 AFDM) occurring during the rainy season and the lowest values $\left(158.90 \pm 79.79 \mu \mathrm{g}\right.$ ergosterol.g- ${ }^{-1}$ AFDM) were registered during the transition rain-dry season (general linear hypotheses, $p<0.01$, Fig. 4A). Aquatic hyphomycetes' conidia production varied seasonally $\left(\chi^{2}(3)\right.$ $=419.2 ; \mathrm{p}<0.001)$. The highest sporulation rates $(33.7 \pm$ 22.42 spores/mg AFDM/day) happened during the dry season and the lowest rates (5.95 \pm 5.11 spores/mg AFDM/day) were registered in transition dry-rain season (general linear hypotheses, $\mathrm{p}<0.01$, Fig. 4B). Eight species of aquatic hyphomycetes were identified on the leaf litter breakdown process; however, richness did not vary among seasons $\left(\chi^{2}\right.$ $(3)=7.144, p=0.067)$. Spearman's correlation coefficient between the fungal community activity (sporulation rate and ergosterol) and the remaining mass showed no correlation ( $p$ $=0.716 ; \mathrm{p}=0.138$, respectively). Ergosterol and sporulation rates did not show correlation either $(\mathrm{p}=0.915)$. Aquatic hyphomycetes' community (occurrence and frequency of species) differed among seasons (PerMANOVA, F $(3,62)$ $=8.4323 ; \mathrm{p}<0.001 ;$ Supplement: Figure SM1), being significantly different for every season comparison (pairwise contrast, Bonferroni, $\mathrm{p}<0.05$ ) except between transition rain-dry and dry seasons. Only the transition rain-dry season did not show an indicator species. Anguillospora filiformis Greath. was an indicator for dry season (IV $=0.32, \mathrm{p}<$ 0.05), Lunulospora curvula Ingold was an indicator for transition dry-rain season (IV $=0.47, \mathrm{p}<0.01)$, Anguillospora longissima (Sacc. \& P. Syd.) Ingold was an indicator for rain season $(\mathrm{IV}=0.19, \mathrm{p}<0.05)$.

During the experimental time, 521 invertebrates were collected from the remaining mass. Nineteen aquatic invertebrate taxa were identified during the study (Supplement: Table SM2). Invertebrate richness variance was not explained by seasons, however invertebrate density variance did $\left(\chi^{2}\right.$ (3) $=12,567, \mathrm{p}<0.01)$. Dry season $(1.95 \pm 2.45$ individual (ind) $\mathrm{g}^{-1}$ ) presented higher (general linear hypotheses, $\mathrm{p}<$ $0,01)$ density values than transition dry-rain $(0.41 \pm 0.29$ ind

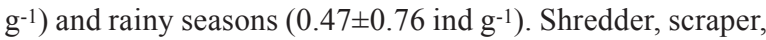
and collector densities (ind $\mathrm{g}^{-1}$ ) did not show significant differences among seasons (Fig. 5). Spearman's correlation coefficient between the shredders and scrapers abundances and the remaining mass showed no correlation $(\mathrm{P}=0.14 ; \mathrm{P}=0.42$, respectively). However, collectors' abundance and remaining mass presented a negative Spearman's correlation coefficient (rho $=-0.37, \mathrm{p}<0.01)$. The invertebrate community expressed by functional groups (Supplement: Table SM3) differed among seasons (PerMANOVA, $F(3,57)=1.9206 ; \mathrm{p}$ $<0.05$; Supplement: Fig. SM2), being significantly different just between transition rain-dry and rain seasons (pairwise contrast, Bonferroni, $\mathrm{p}<0.05$ ), however, no season showed an indicator functional group.

\section{Discussion}

Ecological process and decomposer community interactions

Higher precipitation increased the litter breakdown rates, that could be explained by: (1) an increase in litter fragmenta- 

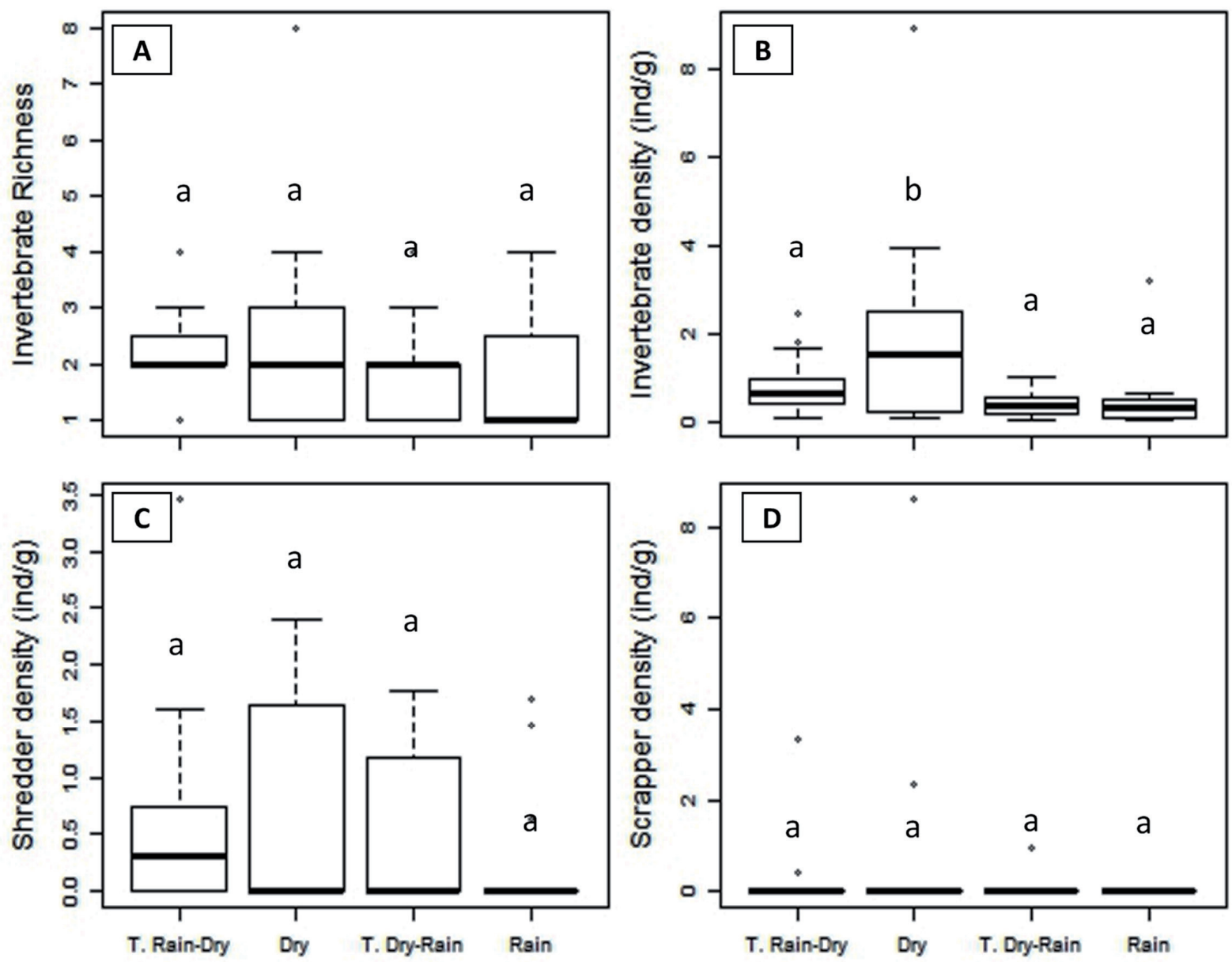

Figure 5. Invertebrate richness (A), invertebrate density (ind/g) (B), shredder density (ind/g) (C), scraper density (ind/g) (D), compared among seasons: T. Rain-Dry (transition rain-dry), Dry (dry), T. Dry-Rain (transition dry-rain), Rain (rain). First (lower line) and third (top line) quartile, the median (bold line), upper and lower limits (dashed line), and outlier (circles). Different letters ("a", "b") indicate significant differences.

tion due to physical abrasion (higher water washing force and stream discharge) (Graça et al. 2015, Wantzen and Wagner 2006, Wootton et al. 2018); or (2) an increase in the activity and exploration of the decomposer community due to higher litter quality input (Gessner et al. 2010, Rezende et al. 2017a). As example, Rueda-Delgado et al. (2006) showed that abiotic factors such as physical abrasion drove the leaf litter breakdown in the Amazonian floodplain. On the other hand, in a global study conducted by Boyero et al. (2016), litter quality explained the variation in the decomposer community and breakdown of native litter. However, low decomposer community abundance during the high peaks of litter breakdown point out that physical fragmentation was the predominant driver of litter breakdown for our system. This last mechanism should be taken carefully and tested in an appropriated experiment.

Furthermore, the percentage of leaf chemical composition did not vary among months. This result indicates that riparian litter composition did not yield a nutritional variability over the system. Low variation in chemical composition may indicate a temporal homogenization of litter quality for riparian savanna systems (Sales et al. 2015). On the other hand, total leaf chemical composition was different just between October and July (Oct > July). This result corresponds with the pattern for AOM input, suggesting that the nutrient input was conducted by the amount of litter input and not to the riparian litter diversity (Bambi et al. 2017, Tonin et al. 2017). Therefore, we can assume that this riparian savanna ecosystem depends more from the litter quantity input than the riparian litter diversity.

Litter breakdown mediated by the fungal-invertebrate interaction may be less efficient and brief in the temporal scale compared to the physical abrasion (Wantzen and Wagner 2006). However, it is important to highlight that these mechanisms are not independent, but maybe hierarchically connected in a general model as shown in Graça et al. (2015). Collectors' abundance showed a negative correlation with litter remaining mass and no seasonal variation. High physical fragmentation of leaf litter may increase fine particulate organic matter and availability of the resource for filtering and gathering collectors invertebrates (Abelho 2001, Cummins et al. 2005). Therefore, the invertebrate community exploited the available resource regardless of ecosystem temporal fluc- 
Table 2. Comparison of litterfall (vertical input; $\left.\mathrm{g} \mathrm{m}^{-2} \mathrm{month}^{-1}\right)$ production and remaining mass $(\%$, month) in various tropical riparian zones.

\begin{tabular}{|c|c|c|c|c|}
\hline Location & Vegetation & $\begin{array}{c}\text { Litterfall } \\
\left(\mathrm{g} \mathrm{m}^{-2} \text { month }^{-1}\right)\end{array}$ & $\begin{array}{l}\text { Leaf remaining } \\
\text { mass }(\%, \text { month) }\end{array}$ & Reference \\
\hline Northeastern Brazil & Brazilian savanna & $24 \pm 17$ & $34 \pm 13$ & This study \\
\hline Northeastern Brazil & Brazilian savanna & $42 \pm 8$ & - & Rezende et al. 2017a \\
\hline Northeastern Brazil & Brazilian savanna & $155 \pm 28$ & $90 \pm 15$ & Sales et al. 2015 \\
\hline Southeastern Brazil & Brazilian savanna & $24 \pm 10$ & - & Gonçalves et al. $2006 \mathrm{a}$ \\
\hline Southeastern Brazil & Brazilian savanna (Veredas) & 15 & 47 & Rezende et al. 2016 \\
\hline Southeastern Brazil & Brazilian savanna & - & $80 \pm 5$ & Alvim et al. 2015 \\
\hline Central Brazil & Brazilian savanna & $83 \pm 2$ & - & Bambi et al. 2016 \\
\hline Southeastern Brazil & $\begin{array}{c}\text { Transition between savanna and } \\
\text { Atlantic forest }\end{array}$ & $30 \pm 5$ & $65 \pm 3$ & Rezende et al. $2017 \mathrm{~b}$ \\
\hline Southeastern Brazil & Atlantic forest & 30 & - & França et al. 2009 \\
\hline \multirow[t]{2}{*}{ Southeastern Brazil } & Atlantic forest & $63 \pm 2$ & - & Gonçalves et al. 2013 \\
\hline & Atlantic forest & $35 \pm 2$ & - & \\
\hline \multirow[t]{2}{*}{ Brazil } & Amazon & $32 \pm 4$ & - & Tonin et al. 2017 \\
\hline & Brazilian savanna & $26 \pm 2$ & - & \\
\hline
\end{tabular}

tuations, with important consequences for the trophic chain of our savanna stream system.

\section{AOM dynamics}

The climatic variations affected the AOM dynamic with the vertical input peak on July, due to an unexpected rainfall in the middle of dry season. The direct input was classified as typical compared with other Brazilian savanna studies (Table 2) and corresponds with the mechanism of an increment in leaf abscission due to hydric stress (Bambi et al. 2017; Gonçalves and Callisto 2013). Therefore, variations in the precipitation year did change the litterfall periodicity, but not the average AOM entering to the system or the litterfall triggers. In a study conducted in the same stream by Rezende et al. (2017b) in the 2011 year, it was found that the inputs were higher compared to the present study four years after (2015). Especially for LI, which was threefold higher in 2011 (159 g.m-2.month-1; Rezende et al. 2017b) than in 2015 (49 g.m $\mathrm{m}^{-2}$.month $\left.{ }^{-1}\right)$. The litterfall inter-annual variation may be explained by changes at the beginning of dry and rain seasons among different years (Bambi et al. 2017). Consequently, AOM availability for the decomposer community would vary depending on the climatic year, affecting directly the leaf breakdown process (Graça et al. 2015).

The mean of VI (24 g.m month $\left.^{-1}\right)$ occupies the low range reported for both Brazilian savanna (24 - 42 g.m ${ }^{-2}$ month-1 $^{-1}$ in Tonin et al. 2017; Rezende et al. 2017a) and tropical riparian zone $\left(9-234\right.$ g.m- month $^{-1}$ in (Zhou et al. 2007, Gonçalves et al. 2014, Kleba Lisboa et al. 2015). The LI (mean of 49 g.m-2 month $^{-1}$ ) was twice bigger than mean VI, indicating that indirect inputs are the major energy source. Higher LI compared to VI may suggest two consequences: (1) indirect inputs are principally constituted by partially de- composed litter, which would imply a succession from terrestrial to aquatic decomposers (Gessner et al. 2010, Rezende et al. 2016); and (2) streams may not depend just from riparian zone inputs, but also from litterfall originated in the most far adjacent forest. BS was not temporally explained, contrary observed to litter input. BS temporal stability is consistent with other Brazilian savanna (Bambi et al. 2017) and tropical stream systems (França et al. 2009). This pattern may be explained by equilibrium between litter input-retention and transport-respiration, suggesting stability in the Brazilian savanna stream ecosystem functioning (Tank et al. 2010). This process also provides a constant stock and probably a long term food resource and habitat heterogeneity for aquatic organisms (Jones 1997, Leite-Rossi et al. 2016).

The riparian leaf richness was different among months showing changes in phenological traits as also observed in other Brazilian savannas and tropical stream systems (França et al. 2009, Kleba Lisboa et al. 2015). From the 15 species, only 6 contributed with more than $5 \%$ in AOM input (mainly by Richeria grandis, with 50\%), as observed in other tropical riparian zones (Gonçalves and Callisto 2013, Rezende et al. 2017b). Higher dominance of few species may indicate that litter composition would not vary drastically through time. Higher leaf dominance is corroborated by total chemical composition, which shows a significant difference only between October and July, suggesting: (1) regular input in nutrient on a small temporal scale, and (2) intra-annual nutrient stability for the ecosystem functioning.

High litter breakdown rates occurred during transitional seasons $(k=-0.035$ in rain-dry; $k=-0.025$ in dry-rain; mainly in May and September) compared to other seasons; both classified as fast according to Gonçalves et al. (2014). Transitional seasons may be a key for understudy the seasonal functioning of ecosystems and nutrient recycling for 
Brazilian savanna streams. Low litter breakdown rate occurred during the rainy season $(k=-0.011)$; this pattern was contrary to what was observed in another Brazilian savanna stream (Rezende et al. 2016) and temperate streams (Abelho 2001, Ferreira et al. 2016), founding the breakdown peak during the precipitation season. During the last months of 2015, the rainy season was affected by a severe drought in the study area and this climatic variation may modify the ecosystem functionality, affecting the carbon and energy flux. Atypical seasons and the changes inflicted over ecosystem mechanisms should be tested in the future through specific experiments.

\section{Fungal communities}

The ergosterol mean $\left(216 \mu \mathrm{g}\right.$ ergosterol. $\left.\mathrm{g}^{-1}\right)$ showed a lower range compared to other Brazilian savanna streams (100 - $900 \mu \mathrm{g}$ ergosterol.g ${ }^{-1}$ in Gonçalves et al. 2007, Alvim et al. 2015, Sales et al. 2015). Sporulation rate (13 spores/ $\mathrm{mg})$ also occupies a low range for tropical streams $(0-231$ spores/mg in Alvim et al. 2015, Rezende et al. 2016, Sales et al. 2015). The conidial production was higher during the dry season, contrary to expected, in which high sporulation rates occur during the rainy season (Graça et al. 2016), by an increase of streamflow and water turbulence (Krauss et al. 2011, Medeiros et al. 2009). Higher conidial production in the dry season may be explained by fastest litter breakdown in the previous season (transition rain-dry), suggesting that intense food resource exploitation increased the metabolic conditions in biomass and energetic terms and favored hyphomycetes reproduction on the next season (Tank et al. 2010). Also, different sporulation levels may suggest that the general environmental conditions were different among seasons (Duarte et al. 2017), affecting directly the hyphomycetes community and indirectly the litter breakdown process (Abelho 2001). Therefore, we can assume that transitional seasons were key for the hyphomycetes' metabolism, as well for the litter breakdown process.

Anguillospora filiformis and Lunulospora curvula were the predominant species during the transitional seasons (the seasons with higher litter breakdown rates) indicating: (1) species may have an opportunistic exploitation behavior and a high degradation activity; and (2) environment conditions selected them (De Wit and Bouvier 2006), regardless their influence over litter breakdown process. The selection by environment conditions may be supported by the negligible differences in enzymatic capacities among fungi species may produce a functional redundancy inside the hyphomycetes community (Gessner et al. 2010). Anguillospora longissima was the indicator of aquatic hyphomycetes species during the rainy season, the season with slower litter breakdown rates. Duarte et al. (2017), found that A. longissima was related to high nitrates and conductivity in the stream water, and the rainy season was the season with higher nitrate levels, specifically during the month of November $(0.18 \mathrm{mg} / \mathrm{L})$. Likewise, and due to slow litter breakdown rates and low water current, $A$. longissima and the hyphomycetes community to which it belonged would have required a more stable litter substrate and environment in or- der to appear, colonize and reproduce (Graça et al. 2016, 2015) The temporal peak of the fungal sporulation rates and invertebrate density during dry season may indicate that the aquatic hyphomycetes' reproductive behavior would have stimulated the appearance and abundance of invertebrates. Flagellospora curvula Ingold was the predominant species (45\%) and Anguillospora filiformis was the indicator species during dry season, and both were cataloged as highly palatable for invertebrate consumption (Butler and Suberkropp 1986, Rong et al. 1995, Gonçalves et al. 2014). Hence, this also may indicate that both species are the ones that most contribute for the fungi ecological influence over the invertebrate community.

\section{Invertebrate communities}

Invertebrate density was low, compared with other Brazilian savanna streams ( 2 to 780 individuals. ${ }^{-1}$ in Ligeiro et al. 2010, Gonçalves et al. 2012, Rezende et al. 2016). Higher invertebrate density was found during dry season by environmental stability and the pool formations due to the lower streamflow in this season (Taylor et al. 2005; Wootton et al. 2018). The family Chironomidae was predominant throughout the whole study, as in most tropical and temperate streams (Ferreira et al. 2016, Moretti et al. 2007, Wantzen and Wagner 2006). We also found a low shredder and scrapers abundance, which is typical for tropical streams (Gonçalves et al. 2006, Vinson and Hawkins 1998). Low density of shredders could be partially explained by i) low litter quality by increase of recalcitrance and low nutritional values in leaf litter of Brazilian savanna compared to other streams ecosystems (Gonçalves et al. 2007, Ligeiro et al. 2010); and ii) low levels of fungal activity (ergosterol and sporulation), which would not produce a litter palatability increment (Graça et al. 2016).

The distinctive element, about changes over invertebrate community structure, was the total scraper absence in the rainy season. This pattern is difficult to reconcile with the environment seasonal conditions, especially regarding two aspects that favored periphyton bloom, the scraper's food resource: (1) the high litter biomass entrance in October implied less canopy cover and consequently an increase in light incidence (Tonin et al. 2018); (2) low precipitation levels during the November and December reduced the streamflow and wherefore its washing force (favoring both, periphyton and scrapers; Cummins and Klug 1979). Nevertheless, the scrapers disappeared from September when the predators reappeared and their abundance was constant until the study end. Therefore, it is probably due to predator persistence that the scraper population was inhibited during the rainy season (Bay 1974).

\section{Conclusion}

Precipitation fluctuations, especially during dry and rainy seasons, affected the litterfall temporal input. However, it did not affect the average organic matter entering the system or the litterfall triggers. Fifteen riparian species were identified, but only Richeria grandis contributed with $50 \%$ of litter 
biomass, helping to explain the stability of nutritional intraannual balance (litter chemistry). Higher sporulation rates and invertebrate density during the dry season suggest that the decomposer community required a more stable environment (consistent low current) to colonize and exploit leaf litter. Despite a decrease in decomposer community attributes, the litter breakdown rates were high for tropical streams. Therefore, we can assume that physical fragmentation was the predominant driver of litter breakdown in our system.

Acknowledgments: C. Calderón received a scholarship from the Coordenação de Aperfeiçoamento de Pessoal de Nivel Superior (CAPES), through the PAEC OEA-GCUB program. This work was financed by Fundação de Amparo à Pesquisa do Estado da Bahia (FAPESB; Process 0022/2013) and by Conselho Nacional de Desenvolvimento Científico e Tecnológico (CNPq) in project number 424661/2016-0. RSR is thankful to CNPq in project number 421288/2017-5 and 405290/2018-7. The authors are thankful to the Parque Municipal de Mucugê staff for its assistance with the field works and the Programa Aquaripária.

\section{References}

Abelho, M. 2001. From litterfall to breakdown in streams: A review Sci. World J. 1:656-680.

Abelho, M. 2016. Litter traits and decomposer complexity set the stage for a global decomposition model. Funct. Ecol. 30:674675.

Alvim, E.A.C.C., Medeiros, A.O., Rezende, R.S. and Gonçalves, J.F. 2015. Small leaf breakdown in a Savannah headwater stream. Limnologica 51:131-138.

APHA. 1999. Standard Methods for Examination of Water and Wastewater. American Public Health Association, American Water Works Association and Water Environmental Federation: Washington, DC, USA.

Bambi, P., de Souza Rezende, R., Feio, M.J., Leite, G.F.M., Alvin ,E., Quintão, J.M.B., Araújo, F. and Gonçalves Júnior, J.F. 2017. Temporal and spatial patterns in inputs and stock of organic matter in savannah streams of Central Brazil. Ecosystems 20: $757-768$.

Bärlocher, F. 2005. Sporulation by aquatic hyphomycetes. In: M.A.S Graça, F. Bärlocher and M.O. Gessner (eds), Methods to Study Litter Decomposition. Springer, Dordrecht. pp. 185-188.

Bärlocher, F. and Graça, M.A.S. 2005. Total Phenolics. In: M.A.S Graça, F. Bärlocher and M.O. Gessner (eds), Methods to Study Litter Decomposition. Springer, Dordrecht. pp. 97-100.

Bates, D.M., Maechler, M., Bolker, B. and Walker, S. 2015. Fitting linear mixed-effects models using lme4. J. Stat. Softw. 67:1-48.

Bay, E.C. 1974. Predator-Prey relationships among aquatic insects Annu. Rev. Entomol. 441-453.

Boulton, A.J., Findlay, S., Marmonier, P., Stanley, E.H. and Valett, H.M. 1998. The functional significance of the hyporheic zone in streams and rivers. Annu. Rev. Ecol. Syst. 29(1):59-81.

Boyero, L., Pearson, R.G., Gessner, M.O. and Dudgeon, D. 2015. Leaf-litter breakdown in tropical streams: Is variability the norm? Freshwater Sci. 34:759-769.

Boyero, L., Pearson, R.G., Hui, C., Gessner, M.O., Pérez, J., Alexandrou, M.A., Graça, M.A.S., Cardinale, B.J., Albariño, R.J., Arunachalam, M., Barmuta, L.A., Boulton, A.J., Bruder, A.,
Callisto, M., Chauvet, E., Death, R.G., Dudgeon, D., Encalada, A.C., Ferreira, V., Figueroa, R., Flecker, A.S., Gonçalves, J.F., Helson, J., Iwata, T., Jinggut, T., Mathooko, J., Mathuriau, C., M'Erimba, C., Moretti, M.S., Pringle, C.M., Ramírez, A., Ratnarajah, L., Rincon, J. and Yule, C.M. 2016. Biotic and abiotic variables influencing plant litter breakdown in streams: A global study. Proc. R. Soc. B Biol. Sci. 283(1829):20152664

Butler, S.K. and Suberkropp, K. 1986. Aquatic hyphomycetes on oak leaves: comparison of growth, degradation and palatability. Mycologia 78:922-928.

Chase, M.W., Christenhusz, M.J.M., Fay, M.F., Byng, J.W., Judd, W.S., Soltis, D.E., Mabberley, D.J., Sennikov, A.N., Soltis, P.S., Stevens, P.F., Briggs, B., Brockington, S., Chautems, A., Clark, J.C., Conran, J., Haston, E., Möller, M., Moore, M., Olmstead, R., Perret, M., Skog, L., Smith, J., Tank, D., Vorontsova, M., and Weber, A. 2016. An update of the Angiosperm Phylogeny Group classification for the orders and families of flowering plants: APG IV. Bot. J. Linn. Soc.

Cummins, K.W. and Klug, M.J. 1979. Feeding ecology of stream invertebrates. Annu. Rev. Ecol. Syst. 10:147-172.

Cummins, K.W., Merritt, R.W. and Andrade, P.C.N. 2005. The use of invertebrate functional groups to characterize ecosystem attributes in selected streams and rivers in south Brazil. Stud. Neotrop. Fauna Environ. 40:69-89.

De Wit, R. and Bouvier, T. 2006. "Everything is everywhere, but, the environment selects"; what did Baas Becking and Beijerinck really say? Environ. Microbiol. 8, 755-758.

Dosskey, M.G., Vidon, P., Gurwick, N.P., Allan, C.J., Duval, T.P. and Lowrance, R. 2010. The role of riparian vegetation in protecting and improving water quality in streams. J. Am. Water Resour. Assoc. 46:261-277.

Duarte, S., Cássio, F. and Pascoal, C. 2017. Environmental drivers are more important for structuring fungal decomposer communities than the geographic distance between streams. Limnetica 36: 491-506.

Dufrêne, M. and Legendre, P. 1997. Species assemblages and indicator species: The need for a flexible asymmetrical approach. Ecol. Monogr. 67:345-366.

Ferreira, V., Castela, J., Rosa, P., Tonin, A.M,. Boyero, L. and Graça, M.A.S. 2016. Aquatic hyphomycetes, benthic macroinvertebrates and leaf litter decomposition in streams naturally differing in riparian vegetation. Aquat. Ecol. 50:711-725.

Ferreira, V., Encalada, A.C. and Graça, M.A.S. 2012. Effects of litter diversity on decomposition and biological colonization of submerged litter in temperate and tropical streams. Freshw. Sci. 31: 945-962.

Ferreira, V., Graça, M.A.S., de Lima, J.L.M.P. and Gomes, R. 2006. Role of physical fragmentation and invertebrate activity in the breakdown rate of leaves. Arch. für Hydrobiol. 165(4):493-513.

Fiuza, P.O., Cantillo-Pérez, T., Monteiro, J.S., Gulis, V. and Gusmão, L.F.P. 2017. Rare hyphomycetes from freshwater environments from Chapada Diamantina, Bahia, Brazil. Nov. Hedwigia. 104(4):451-466.

França, J.S., Gregório, R.S., D’Arc De Paula, J., Gonçalves Júnior J.F., Ferreira, F.A. and Callisto, M. 2009. Composition and dynamics of allochthonous organic matter inputs and benthic stock in a Brazilian stream. Mar. Freshw. Res. 60:990-998.

García-Palacios, P., Mckie, B.G., Handa, I.T., Frainer, A. and Hättenschwiler, S. 2016. The importance of litter traits and decomposers for litter decomposition: A comparison of aquatic and terrestrial ecosystems within and across biomes. Funct. Ecol. 30: 819-829. 
Gessner, M.O. 2005. Ergosterol as a measure of fungal biomass. In: M.A.S. Graça, F. Bärlocher and M.O. Gessner (eds), Methods to Study Litter Decomposition. Springer, Dordrecht. pp. 189-195."

Gessner, M.O., Swan, C.M., Dang, C.K., McKie, B.G, Bardgett, R.D., Wall, D.H. and Hättenschwiler, S. 2010. Diversity meets decomposition. Trends Ecol. Evol. 25:372-380.

Gonçalves, A.L., Chauvet, E. Bärlocher, F., Graça, M.A.S. and Canhoto, C. 2014. Top-down and bottom-up control of litter decomposers in streams. Freshw. Biol. 59:2172-2182.

Gonçalves, J.F. and Callisto, M. 2013. Organic-matter dynamics in the riparian zone of a tropical headwater stream in Southern Brasil. Aquat. Bot. 109:8-13.

Gonçalves, J.F., Rezende, R.S., Gregório, R.S. and Valentin, G.C. 2014. Relationship between dynamics of litterfall and riparian plant species in a tropical stream. Limnologica 44:40-48.

Gonçalves, J.F., Graça, M.A.S. and Callisto, M. 2007. Litter decomposition in a Cerrado savannah stream is retarded by leaf toughness, low dissolved nutrients and a low density of shredders. Freshw. Biol. 52(8):1440-1451.

Gonçalves, J.F., Graça, M.A.S. and Callisto, M. 2006. Leaf-litter breakdown in 3 streams in temperate, Mediterranean, and tropical Cerrado climates. J. North Am. Benthol. Soc. 25(2):344-355.

Gonçalves, J.F., Rezende, R.S., França, J. and Callisto, M. 2012. Invertebrate colonisation during leaf processing of native, exotic and artificial detritus in a tropical stream. Mar. Freshw. Res. 63(5). 428-439.

Graça, M.A.S., Ferreira, V., Canhoto, C., Encalada, A.C., GuerreroBolaño, F., Wantzen, K.M. and Boyero, L. 2015. A conceptual model of litter breakdown in low order streams. Int. Rev Hydrobiol. 100:1-12.

Graça, M.A.S., Hyde, K. and Chauvet, E. 2016. Aquatic hyphomycetes and litter decomposition in tropical - subtropical low order streams. Fungal Ecol. 19:182-189.

Gulis, V., Marvanová, L. and Descals, E. 2005. An illustrated key to the common temperate species of aquatic hyphomycetes. In: M.A.S. Graça, F. Bärlocher and M.O. Gessner (eds), Methods to Study Litter Decomposition. Springer, Dordrecht. pp. 153-167.

Gulis, V. and Suberkropp, K. 2003. Leaf litter decomposition and microbial activity in nutrient-enriched and unaltered reaches of a headwater stream. Freshw. Biol. 48(1):123-134.

Hamada, N., Nessimian, J.L. and Querino, R.B. 2014. Insetos Aquáticos na Amazônia brasileira: taxonomia, biologia e ecologia. Editora do INPA, Manaus.

Hothorn, T., Bretz, F. and Hothorn, M.T. 2009. The multcomp package. The R Project for Statistical Computing.

Jones, J.B. 1997. Benthic Organic Matter Storage in Streams: Influence of Detrital Import and Export, Retention Mechanisms, and Climate. J. North Am. Benthol. Soc. 16:109-119.

Juncá, F.A., Funch, L. and Rocha, W.D.F. 2005. Biodiversidade e Conservação da Chapada Diamantina, Brasília: Ministério do meio ambiente.

Kleba Lisboa, L., Lemes Da Silva, A.L., Siegloch, A.E., Gonçalves, J.F. and Mello Petrucio, M. 2015. Temporal dynamics of allochthonous coarse particulate organic matter in a subtropical Atlantic rainforest Brazilian stream. Mar. Freshw. Res. 66(8): 674-680.

Krauss, G.J., Solé, M., Krauss, G., Schlosser, D., Wesenberg, D. and Bärlocher, F. 2011. Fungi in freshwaters: Ecology, physiology and biochemical potential. FEMS Microbiol. Rev. 35(4):620651.

Leite-Rossi, L.A., Saito, V.S., Cunha-Santino, M.B. and TrivinhoStrixino, S. 2016. How does leaf litter chemistry influence its decomposition and colonization by shredder Chironomidae (Diptera) larvae in a tropical stream? Hydrobiologia. 771:119130.

Li, A.O. and Dudgeon, D. 2009. Effects of leaf toughness and nitrogen content on litter breakdown and macroinvertebrates in a tropical stream. Aquat. Sci. 71:80-93.

Ligeiro, R., Moretti, M.S., Gonçalves, J.F. and Callisto, M. 2010. What is more important for invertebrate colonization in a stream with low-quality litter inputs: Exposure time or leaf species? Hydrobiologia 654:125-136.

Marques, J.J., Schulze, D.G., Curi, N. and Mertzman, S.A. 2004. Major element geochemistry and geomorphic relationships in Brazilian Cerrado soils. Geoderma 119(3-4):179-195.

Medeiros, A.O., Pascoal, C. and Graça, M.A.S. 2009. Diversity and activity of aquatic fungi under low oxygen conditions. Freshw. Biol. 54:142-149.

Moretti, M., Gonçalves, J.F. and Callisto, M. 2007. Leaf breakdown in two tropical streams: Differences between single and mixed species packs. Limnologica 37:250-258.

Mugnai, R., Nessimian, J. L. and Baptista, D. F. 2010. Manual de identificação de macroinvertebrados aquáticos do Estado do Rio de Janeiro: para atividades técnicas, de ensino e treinamento em programas de avaliação da qualidade ecológica dos ecossistemas lóticos. Technical Books Editora, Rio de Janeiro.

Ordoñez, J.C., Van Bodegom, P.M., Witte, J.P.M., Wright, I.J., Reich, P.B. and Aerts, R. 2009. A global study of relationships between leaf traits, climate and soil measures of nutrient fertility. Glob. Ecol. Biogeogr. 18(2):137-149.

Parron, L.M., Bustamante, M.M.C. and Markewitz, D. 2011. Fluxes of nitrogen and phosphorus in a gallery forest in the Cerrado of central Brazil. Biogeochemistry. 105(1-3):89-104.

Peters, D.P.C., Bestelmeyer, B.T., and Turner, M.G. 2007. Crossscale interactions and changing pattern-process relationships: Consequences for system dynamics. Ecosystems 10(5):790-796.

Rezende, R.S., Correia, P.R.S., Gonçalves, J.F. and Santos, A.M. 2017a. Organic matter dynamics in a savanna transition riparian zone: Input of plant reproductive parts increases leaf breakdown process. J. Limnol. 76(3):502-511.

Rezende, R.S., Graça, M.A.S., Santos, A.M., Medeiros, A.O., Santos, P.F., Nunes, Y.R. and Gonçalves, J.F. 2016. Organic Matter Dynamics in a Tropical Gallery Forest in a Grassland Landscape. Biotropica. 48:1-10.

Rezende, R.S., Sales, M.A., Hurbath, F., Roque, N., Gonçalves, J.F. and Medeiros, A.O. 2017b. Effect of plant richness on the dynamics of coarse particulate organic matter in a Brazilian Savannah stream. Limnologica 63:57-64.

Rong, Q., Sridhar, K.R. and Bärlocher, F. 1995. Food selection in three leaf-shredding stream invertebrates. Hydrobiologia 316(3): 173-181.

Rueda-Delgado, G., Wantzen, K.M. and Tolosa, M.B. 2006. Leaflitter decomposition in an Amazonian floodplain stream: Effects of seasonal hydrological changes. J. North Am. Benthol. Soc. 25(1):233-249.

Sales, M.A., Gonçalves, J.F., Dahora, J.S. and Medeiros, A.O. 2015. Influence of Leaf Quality in Microbial Decomposition in a Headwater Stream in the Brazilian Cerrado: A 1-Year Study. Microb. Ecol. 69:84-94.

Santos, K.A., dos Oliveira Junior, I., De Pedreira, P.D. and Santos, N.A. 2017. Gestão ambiental de unidades de conservação: uma análise do parque municipal de Mucugê-Bahia. Geogr. Dep. Univ. Sao Paulo. 
Shaftel, R.S., King, R.S. and Back, J.A. 2012. Alder cover drives nitrogen availability in Kenai lowland headwater streams, Alaska. Biogeochemistry 107(1-3):135-148.

Suberkropp, K. and Klug, M.J. 1976. Fungi and Bacteria Associated with Leaves During Processing in a Woodland Stream. Ecology 57(4):707-719.

Tank, J.L., Rosi-Marshall, E.J., Griffiths, N.A., Entrekin, S.A. and Stephen, M.L. 2010. A review of allochthonous organic matter dynamics and metabolism in streams. J. North Am. Benthol. Soc. 29:118-146.

Taylor, P., Fenoglio, S., Bo, T., Agosta, P. and Malacarne, G. 2005. Temporal and Spatial Patterns of Coarse Particulate Organic Matter and Macroinvertebrate Distribution in a Low- Order Apennine Stream. J. Freshw. Ecol. 20:539-547.

Tonin, A.M., Gonçalves, J.F., Bambi, P., Couceiro, S.R.M., Feitoza, L.A.M., Fontana, L.E., Hamada, N., Hepp, L.U., LezanKowalczuk, V.G., Leite, G.F.M., Lemes-Silva, A.L., Lisboa, L.K., Loureiro, R.C., Martins, R.T., Medeiros, A.O., Morais, P.B., Moretto, Y., Oliveria, P.C.A., Pereira, E.B., Ferreira, L.P., Pérez, J., Petrucio, M.M., Reis, D.F., Rezende, R., Roque, N., Santos, L.E.P., Siegloch, A.E., Tonello, G. and Boyero, L. 2017. Plant litter dynamics in the forest-stream interface: Precipitation is a major control across tropical biomes. Sci. Rep. 7:1-14.

Tonin, A.M., Ubiratan Hepp, L. and Gonçalves, J.F. 2018. Spatial variability of plant litter decomposition in stream networks: From litter bags to watersheds. Ecosystems 21:567-581.

Vinson, M.R. and Hawkins, C.P. 1998. Biodiversity of stream insects: variation at local, basin, and regional scales. Annu. Rev. Entomol. 43(1):271-293

Wantzen, K.M. 2003. Cerrado streams - Characteristics of a threatened freshwater ecosystem type on the Tertiary Shields of Central South America. Amazoniana 17(3/4):481-502.

Wantzen, K.M. and Wagner, R. 2006. Detritus processing by invertebrate shredders: a neotropical-temperate comparison. J. North Am. Benthol. Soc. 25:216-232.
Webster, J.R. and Meyer, J.L. 1997. Organic matter budgets for streams: A synthesis. J. North Am. Benthol. Soc. 16:141-161.

Wootton, A., Pearson, R.G. and Boyero, L. 2018. Patterns of flow, leaf litter and shredder abundance in a tropical stream. Hydrobiologia 826(1):353-365.

Zhou, G., Guan, L., Wei, X., Zhang, D., Zhang, Q., Yan, J., Wen, D., Liu, J., Liu, S., Huang, Z., Kong, G., Mo, J. and Yu, Q. 2007. Litterfall production along successional and altitudinal gradients of subtropical monsoon evergreen broadleaved forests in Guangdong, China. Plant Ecol. 188(1):77-89.

Received April 21, 2019

Revised November 11, 2019 Accepted December 10, 2019

\section{Supplementary Material}

\section{R scripts}

Figure SM1. Hyphomycetes species relative abundance (\%) through the different experimental seasons

Figure SM2. Trophic functional group relative abundance (\%) through the different experimental seasons.

Table SM1. Mean values of the physical and chemical $(\mathrm{mg} / \mathrm{L})$ variables in the Boiadeiro stream during the study period (February 2015 to January 2016).

Table SM2. Monthly mean values (and SD) of the invertebrate density (ind/g) during the different seasons.

Table SM3. Invertebrate taxa and correspondent Functional Groups.

The file may be downloaded from www.akademiai.com. 